\title{
Inventory and Protection of Photographs from the Julij Felaher Collection
}

\author{
LUCIJA PLANINC, MRS.
}

Conservation and Restoration Adviser, Archives of the Republic of Slovenia. Zvezdarska 1, SI-1000 Ljubljana

MARIJA GRABNAR, DR.

Senior Adviser, Archivist, Archives of the Republic of Slovenia. Zvezdarska 1, SI-1000 Ljubljana

e-mail: Marija.Grabnar@gov.si

JeDERT VODOPIVEC TOMAŽlČ, PH.D. PROF.

Head of Conservation Department, Archives of the Republic of Slovenia. Zvezdarska 1, SI-1000 Ljubljana

e-mail: jedert.vodopivec@gov.si

Inventory and Protection of Photographs from the Julij Felaher Collection

ABSTRACT

Photographs bear visual memories of events, people, buildings and landscapes. The sensitivity of the materials used makes them a vulnerable part of cultural heritage, therefore their appropriate use and storage is ever more important. The work presented is based on an inventory of photographs from the Julij Felaher Collection (SI AS 1384) kept by the Archives of the Republic of Slovenia. In addition to basic information, the inventory sheet used also included reference to the type of photographic technique, the type of primary support, the type of damage, and an assessment of the preservation status. Based on the data obtained, physical protection of the photographs was carried out in order to enable their permanent storage.

Key words: Felaher, Julij, Carinthian Slovenians, history of photography, photographic material, archival material, Archive of the Republic of Slovenia

Inventario e protezione delle fotografie dalla collezione Julij Felaher

\section{SINTESI}

Le fotografie portano memorie visive di eventi, persone, edifici e paesaggi. La sensibilità dei materiali utilizzati li rende una parte vulnerabile del patrimonio culturale, pertanto il loro uso appropriato e la loro conservazione è sempre più importante. Il presente lavoro è basato su un inventario delle fotografie dalla collezione Felaher Julij (SI AS 1384) conservato dagli archivi della Repubblica di Slovenia. Oltre alle informazioni di base, il foglio di inventario usato include anche riferimenti al tipo di tecnica fotografica, al tipo di supporto primario, al tipo di danno ed alla valutazione dello stato di conservazione. Sulla base dei dati ottenuti, una protezione fisica delle fotografie è stata effettuata al fine di consentire il loro deposito permanente.

Parole chiave: Felaher, Julij, sloveni della Carinzia, storia della fotografia, materiale fotografico, materiale d'archivio, Archivio della Repubblica di Slovenia

\section{Inventar in zaščita fotografij iz zbirke Julija Felaherja}

\section{IZVLE ¿̌EK}

Fotografije so nosilke spomina vizualnih sporočil o dogodkih, ljudeh, zgradbah in pokrajinah. So tisti del kulturne dediščine, ki je ranljiv že zaradi občutljivosti materialov, zato je toliko bolj pomembna njihova pravilna uporaba in hramba. Predstavljeno delo temelji na materialnem popisu fotografij osebnega fonda Julij Felaher (SI AS 1384), ki ga hrani Arhiv Republike Slovenije. Pri tem je bil uporabljen popisni obrazec, ki poleg osnovnih podatkov o fotografiji povzame tudi vrsto fotografske tehnike, vrsto nosilca zapisa, vrsto poškodb in oceno stanja ohranjenosti. Na podlagi tako pridobljenih podatkov je bila izpeljana materialna zaščita, ki omogoča trajno hrambo fotografij.

Ključne besede: Felaher, Julij, koroški Slovenci, zgodovina fotografije, fotografsko gradivo, arhivsko gradivo, Arhiv Republike Slovenije 


\section{Introduction}

\section{The subject and objectives of the research ${ }^{1}$}

The research covers 604 analogue photographs from the Julij Felaher Collection (SI AS 1384) kept by the Archives of the Republic of Slovenia. Because of their topic and in particular the rareness of certain images, they are classified as archival material of exceptional importance related to the history of Carinthian Slovenians.

The research objectives were to create a transparent and coherent model for inventory taking of photographs, to assess their preservation status, and to contribute to arrangements for their physical protection.

All photographs were physically examined and simultaneously inventoried using an inventory sheet for photographs. In addition to basic data such as the title, the year the photograph was taken, the name of the photographer and studio, and the dimensions of the photograph, the sheet also includes the type of photograph, the type of primary support, the type of damage and an assessment of the preservation status. These data were also presented in a summary table that provided the basis for deciding on the choice of protective materials for permanent storage of the photographs.

Our aim was to establish the foundations for appropriate and comprehensive storage solutions for photographic collections in archives, libraries, museums, galleries and other similar institutions.

\section{Julij Felaher, photography collector, his life and work}

Julij Felaher was a well-known Carinthian Slovenian who dedicated his creative life to Carinthian Slovenians; he was born on 3 January 1895 in Melviče / Mellweg in the municipality of Brdo / Egg in the county of Śmohor / Hermagor in the Ziljska / Gailtal Valley, at the westernmost edge of the territory inhabited by Slovenians in Carinthia (see Fig. 1). He attended the primary school in his hometown, graduated from a humanistic secondary school in Celovec / Klagenfurt, enrolled in law studies at the University of Vienna, continued his studies in Zagreb, and finished his $\mathrm{PhD}$ at the University of Ljubljana in 1922. He worked as a legal trainee at the Ljubljana District Court and passed the state lawyers' examination at the Ljubljana Higher Regional Court in 1925 . He actively cooperated with the Minority Institute in Ljubljana from that year on. ${ }^{2} \mathrm{He}$ studied minority law and wrote articles about Carinthian Slovenians and their legal, cultural, economic and social status as well as about general issues concerning their minority status. At the end of the Second World War, he became a judge at the Ljubljana District Court and was appointed to oversee the take over of all courts, court buildings, prisons, and detention institutions in the territory of Carinthia, including all their belongings, files, archives and land registers. He was also a member of a special commission with the Executive Committee of the Liberation Front; in the two months of its operation, it gathered documents for the Ministry of Foreign Affairs related to the coming peace conference, and handled the most urgent organisational matters concerning Carinthia after the liberation.

In the period 1945-1948 he was a clerk at the Scientific Institute of the Presidium of the Slovene National Liberation Committee in Ljubljana and thereafter, until his retirement in 1959, a research fellow at the Institute for Ethnic Studies at the University of Ljubljana.

Felaher was never actively engaged in politics. He only participated in culture, sports, and education, and was interested in ethnic minority and information related to Carinthia; due to his profound knowledge of the situation in Carinthia, he was considered a reference source within the Institute and by others in matters concerning Carinthian Slovenians.

As a lecturer, he attended countless meetings and gatherings on various occasions, visited schools,

1. The extended version of this paper was published in the journal Arbivi (2012 /1, pp. 249-264) but, due to the significance of the subject-matter discussed, it has been shortened and translated into English to make it more available to a wider audience.

2. The Minority Institute operated in Ljubljana in the period 1925-1941. It dealt with the status of Slovenians in the neighbouring countries, and that of German and Hungarian minorities in Slovenia. Its successor is the existing Institute for Ethnic Studies in Ljubljana. See: Strgar, Janez: Sedem desetletij Inštituta za narodnostna vprašanja. Ljubljana 1995. 
student associations, appeared on radio programmes, and analysed and explained the status and situation of Carinthian Slovenians. In the post-war period, he and the „old guard“ at the Institute for Ethnic Studies had been a target for ideological criticism and were involuntarily retired after a few years. He died on 28 May 1969 in Ljubljana. ${ }^{3}$

\section{Julij Felaher's legacy}

The legacy of Julij Felaher is kept by the Archives of the Republic of Slovenia as the Julij Felaher Collection (SI AS 1384). In addition to photographs, it also contains his personal documents and letters, books, maps, charts, Ordinance survey maps, materials related to the Carinthian Slovenians Club, manuscripts and typescripts. The Archives inventory has not been completed, but it is estimated to consist of approximately 46 boxes, i.e. 4.8 linear metres. ${ }^{4}$

Part of the legacy of Julij Felaher is kept by the former Reference Library, Ravne na Koroškem, now the Dr Franc Sušnik Central Library of Carinthia. Upon the arrival of a large quantity of documents at the library, some items were selected and placed in special safe deposit boxes (at the time of Dr Franc Sušnik). These items include, in particular, photographic material featuring the battles for the northern border, postcards of places in Carinthia (partly already processed in the COBISS system and available at $\mathrm{dLibu}$ ) and correspondence of Carinthian compatriots. Some of the photographic material has been treated by the Library and the online presentation thereof prepared. ${ }^{5}$

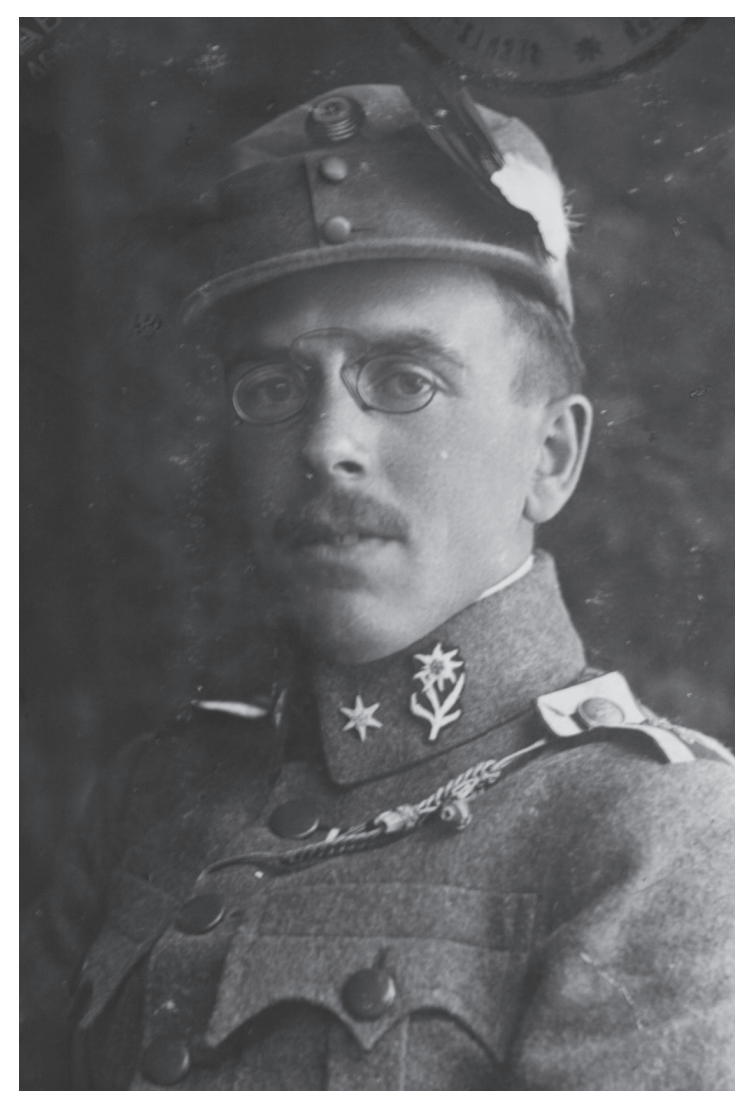

Figure 1: Portrait photographs of Julij Felaher in an Austrian Lieutenant's uniform, from the University of Vienna index. Taken between 1915-1918

3. Information obtained from the doctoral dissertation of Dr Danijel Grafenauer entitled "Življenje in delo Julija Felaherja in koroški Slovenci”. Available at: http://dkum.uni-mb.si/IzpisGradiva.php?id=11339\#.

4. The data provided by Marija Grabnar indicate that the quantity greatly exceeds that presented in the "Vodnik po fondih in zbirkah Arbiva Republike Slovenije" (Ljubljana 1999, Book III, p. 176).

5. Submitted by Simona Šuler-Pandev, univ. dipl. soc., Librarian Specialist, local studies coordinator at the Dr Franc Sušnik Central Library of Carinthia. 


\section{What is a photograph?}

The word „photograph“ derives from ancient Greek and means writing with light ( $\varphi \omega \tau \circ$ s: photos

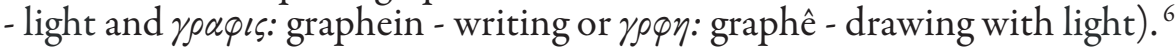

Today, photographs are present in all areas of human cultural, scientific, professional and educational activities. Photographs are differentiated based on the photographic technique used or their production in analogue or digital form. An analogue photograph is produced through a gradual change in the image medium, usually based on a chemical process (photographic film). It is composed of the primary support and two, three or more image layers. Nowadays, this technique has been almost entirely replaced by digital photography, ${ }^{7}$ which uses light-sensitive sensors to capture an image focused on by a lens, and not the exposure of a light-sensitive film. When a photograph is taken it is stored as a digital file ready for digital processing, viewing or printing. A digital photograph is a positive; its creation does not require a negative or darkroom.

\section{Analogue photograph structure and type of primary support}

An analogue photograph (a negative and a positive) is composed of two or more different layers on a particular primary support. ${ }^{8}$

The primary support can be glass, porcelain, metal (tin, copper, iron) and plastic (nitrate, acetate, polyester). The binders used in a photograph have changed with the development of photography. At first, albumin (egg white) was used, followed by collodion (nitrocellulose); most often gelatin binders are found in photographs.

The final image layer is a photo-sensitive substance. In black and white photographs, these substances most often contained of silver, while in colour and monochrome photographs these substances consisted of different dyes and pigments and other non-silver substances usually dispersed in the binder layer of the photograph. ${ }^{9}$

The history of photography reveals many types of photographs: daguerreotype, ferotype, ambrotype, calotype, albumen photographs, silver gelatin photographs, collodion photographs, platinotype, carbon photographs, photographs using photo-mechanic processes: collotype, raster printing, and others.

\section{METHOD OF WORK}

Our aim was to produce an inventory of photographs that would significantly complement the existing inventory of the Archives and also be useful in planning physical protection.

We physically examined each photograph and took the inventory based on the inventory sheet ${ }^{10}$ used by the conservators and restorers when photographs are handed over to them.

The photographs were inventoried based on three elements taken from the inventory of the Archives, in particular, the title, the period of origin, and the serial number; material descriptions of the photographers and studios, the primary support dimensions, the type of photograph, and colours (black and white or colour) were added together with data on positives or negatives, and a description of any damage.

Material descriptions are important for the organisation of sustainable protection; some inventory elements, such as the type of photograph, are vital. It should be emphasised in this context that the identification of the type of photograph is a demanding job that requires an experienced expert.

6. Snoj, Marko: Slovenski etimološki slovar. Ljubljana: Mladinska knjiga, 1997, p. 130.

7. Jürgens, Martin C.: The Digital Print (Identification and Preservation). Los Angeles: The Getty Conservation Institute, 2009, pp. 3-39.

8. Ajdič, Peter: Fotografska kemija 1. Ljubljana: Državna založba Slovenije, 1986, p. 12.

9. Ibid. p. 84.

10. Available at: http://www.arhivsko-drustvo.si/Arhivi/Arhivi_2012_1.pdf. 
Based on the inventorying and identification of photographs, ${ }^{11}$ we assessed the preservation status of the photographs, restored them, and selected the appropriate materials for their permanent storage.

\section{Storage of photographs, and the scope, period of origin, and subject matter thereof}

Photographic material is part of the SI AS 1348 collection stored in the repositories of the Archives of the Republic of Slovenia, in the Virant House at Zvezdarska ulica 1; access is possible from the reading room at the same location. This material was stored in two archival boxes marked Nos. 22 and 23. The first and the second boxes contain 219 and 385 photographs, respectively, and also include positives and many postcards and negatives. The archival boxes were made by the domestic manufacturer Paloma, based in Ceršak. They are of standard dimensions, i.e. $26.5 \times 38.5 \times 10 \mathrm{~cm}$, and are made of paperboard; the composition of the raw materials does not meet the standards for archival protective materials.

As to their subject matter, the photographs are classified as:

a. a) portrait photographs: group photographs, photographs of individuals, and photographs of distinguished Carinthians;

b. b) genre photographs: photographs showing important political events and traditions of village, social and church life;

c. c) documentary photographs: these are postcards of localities, mostly from Austrian Carinthia.

The now Germanised names of these places and traditions, which have only rarely been kept alive, render these photographs precious. They were taken in the period from the end of the $19^{\text {th }}$ century to the mid $20^{\text {th }}$ century. There are numerous postcards and photographs of localities (207), including one of the oldest, dating back to 1894, depicting Lake Belopeško / Lago di Fusine. An even older postcard was issued by the Slovenian Christian Social Society of Celovec / Klagenfurt before 1894 and depicts a group of actors in the play Miklova Zala staged in Celovec / Klagenfurt. One of the recent postcards dates to 1948 and features girls from Brnca / Fürnitz attending a traditional event, a štehvanjska konta.

Photographic material storage conditions before transfer to the Archives of the Republic of Slovenia ${ }^{12}$

Together with other items in the collection (SI AS 1384), the photographs were handed over to the Archives of the Republic of Slovenia in 1969, and in 1970 by Dr Tone Zorn (1934-1981), a Senior Research Fellow at the Institute for Ethnic Studies and Head of the Department for Ethnic Studies along the Northern Border until 1970, who was also a friend of Julij Felaher, who had been employed at the same Department. After Felaher died in 1969, Zorn probably assessed that as a source of knowledge regarding Carinthia and research thereon, the legacy belonged to the public archives.

It can be seen from Felaher's correspondence with his fellow Carinthians that he collected pictorial material in a spontaneous and unsystematic manner, but with the awareness that it provided an important additional illustration of written words. Most often photographs were brought or sent to him at his request by people who took them or by those who participated in the events featured.

The type of material allows the conclusion that Julij Felaher kept private documents and a portion of the pictorial materials (photographs of relatives, postcards) at his home. Tone Zorn handed these materials over to the Archives of the Republic of Slovenia together with the legacy kept at the Institute for Ethnic Studies.Unfortunately, there are no data regarding the conditions in which people stored the photographs before sending them to the collector. There is also no information about how Mr Felaher housed them, about the location in the house where they were kept, about the folders, wrappers, cabinets, drawers used, or the temperature and humidity of the rooms.

When the legacy was handed over to the Archives of the Republic of Slovenia, the photographic material was not separated from other material and was not subject to any special treatment. Initially, the photographs were kept in already used, decaying, partially torn paper folders; some were thematically

11. The identification of photographs was carried out by Lucija Planinc.

12. Data provided by Marija Grabnar. 
arranged, but most often they were simply tied up in bundles with other materials (see Fig. 2). When arranging and taking the inventory in the Archives, the material concerned and the photographs were stored in the aforementioned archival boxes; within the boxes, materials were subdivided and placed in paperboard flap folders, size A4, which are convenient for document filing. The photographs were put in letter envelopes for better protection.

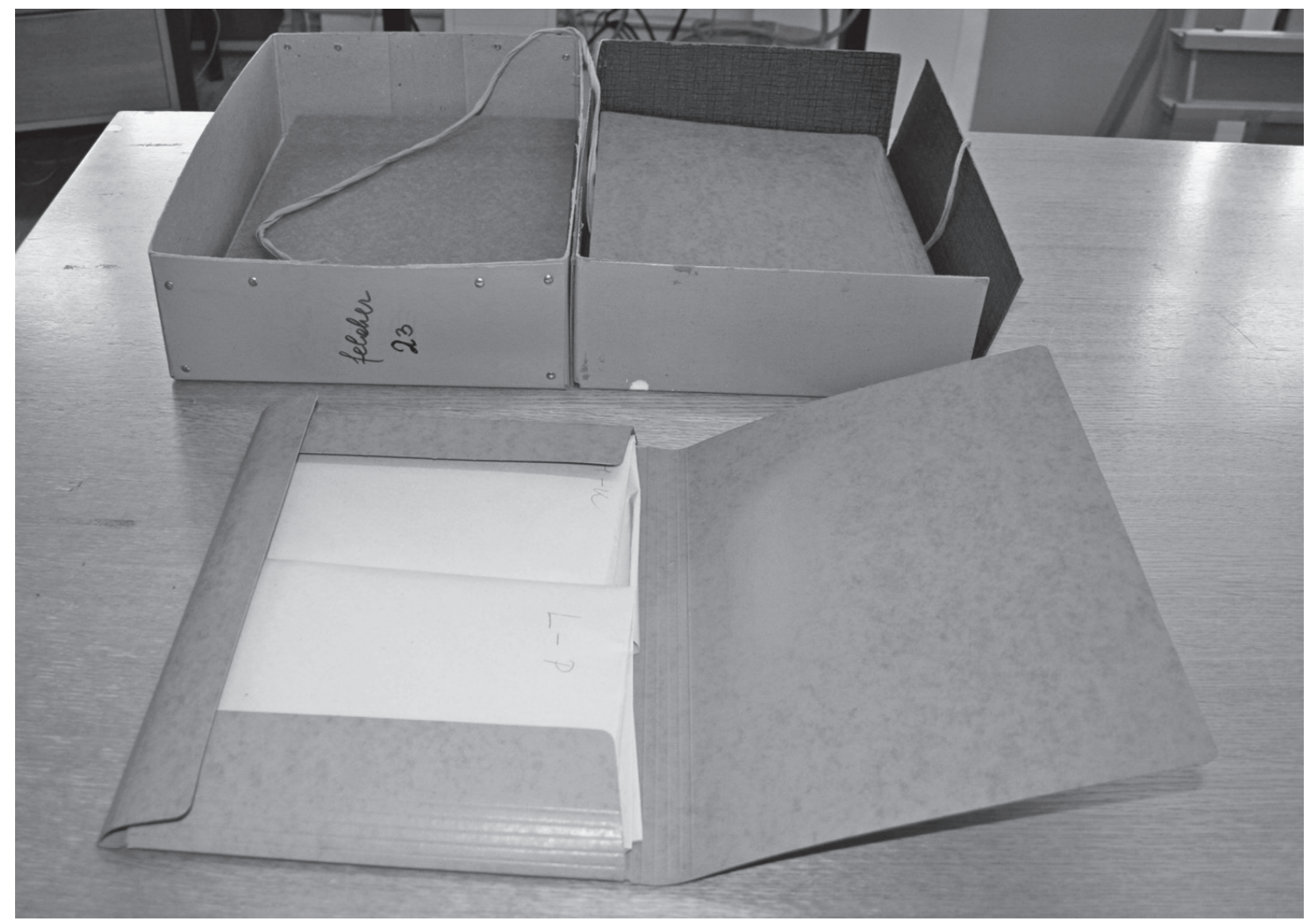

Figure 2: The photographs after being properly arranged: the archival box with open blue paperboard folder and the photographs placed in the letter envelopes (Photo: Mirjam Debevc)

\section{Inventory taking ${ }^{13}$}

The inventory of 604 units ( 1 photograph $=1$ unit), including a description of their status, was taken in the Archives of the Republic of Slovenia, Zvezdartska ulica 1, in the period from 1-28 April 2010.

The work was carried out in the following successive phases:

1. numbering;

2. identification;

3. simultaneous recording of data in the inventory sheet and the summary inventory table;

4. the drafting of summary descriptions and preparation of physical protection.

1) Numbering is a basic and important phase carried out prior to other phases. Each photograph is assigned a serial number and hence a specific location within the collection. Thus, disorder and confusion in further handling are prevented or at least minimised. The number accompanies the photograph in all subsequent conservation treatments, scanning, digitising, etc. A B4 pencil was used for numbering. ${ }^{14}$ The

13. The detailed inventory was taken in the Archives of the Republic of Slovenia by Archivist Eva Gerkman.

14. The archival items are marked using graphic pencils B1 to B8, which leave no embossed print and do not react chemically with the writing substrate (note by Lucija Planinc). 
first serial number was assigned to the first photograph in the first folder of the first box (box No. 22 of the existing Archive inventory). We continued with the second folder of the same box and carried on until the last folder in the subsequent box, No. 23. The number was pencilled in the bottom right-hand corner on the back.

2) The initial identification of the type of photograph was performed visually, as each type of photograph has its specific colour and shade range. Each photograph was identified as a colour or a black and white photograph, or as a positive or negative. The age of the photograph ${ }^{15}$ was determined using the dates and other identification elements on the photographs; its dimensions were measured (the size of the primary support). To identify the type of photograph more accurately, a magnifier enabling 100 times magnification was used. Smooth white cotton gloves were used to handle the photographs. Albumen, collodion, silver gelatin photographs and photomechanical lithographs, collotypes and raster printings (colour and black and white) were identified.

3) Data for each photograph were recorded in the inventory sheet (stored in electronic form); in order to enable a simplified and faster overview, all 604 photographs were also recorded in the summary inventory table.

4) Based thereon, four charts were produced showing the proportion of the types of individual photographs, the proportion of black and white and colour photographs, the proportion of positives and negatives, and the proportion of damaged photographs. The data from the summary inventory table also indicated the necessary conservation procedures and physical protection.

\section{RESULTS}

Using the summary inventory table, the following results were produced:

- the proportion of the various types of individual photographs;

- the proportion of black and white and colour photographs;

- the proportion of positives and negatives;

- the proportion of damaged and undamaged photographs.

Types of photographs: Silver gelatin photographs outnumber all other types by far ( 492 photographs out of a total of 604), some are albumen (3), and some collodion (3). These are followed by four types of photomechanical photographs: collotypes ( 54 colour or black and white), halftone techniques ( 29 colour or black and white), lithographs ( 4 colour or black and white) and one roto engraving (which is a halftone technique). There are also some silver gelatin negatives: 10 on polyester and one on glass. We failed to identify nine photographs.

Proportion of black and white and colour photographs: Black and white photographs are predominant (573), there are far (33) fewer colour photos.

Proportion of positives and negatives: The great majority are positives (595), there are only a few (11) negatives.

Proportion of damaged photographs: The share of damaged photographs is substantial, also due to the fact that dusty photographs are classified as damaged. Other types of damage include tears, missing areas, silver mirroring, folds, mould, foxing, fingerprints, and other stains and rust.

\section{Description of damage}

Photographs are more prone to a continuous and inevitable natural aging process than other documents. This process can be slowed down and many types of damage can be avoided through careful handling, appropriate climate conditions, and suitable physical protection. As a rule, damage depends on internal and external factors. The internal factors include the quality of the primary support and image layer materials. The external factors that cause damage include inappropriate handling and inappropriate climate conditions. 
Lucija PLANINC -Marija GRABNAR - Jedert VODOPIVEC TOMAŽIČ: Inventar in zaščita fotografij iz zbirke Julija Felaherja, 91-102

\section{Foxing $^{16}$}

Foxing appears in old photographs as fine red-brown randomly dispersed stains on the paper primary support (see Fig. 3). Experts are still not absolutely certain why foxing occurs, but it is known that, like moulds, foxing appears in bright, warm and humid places.

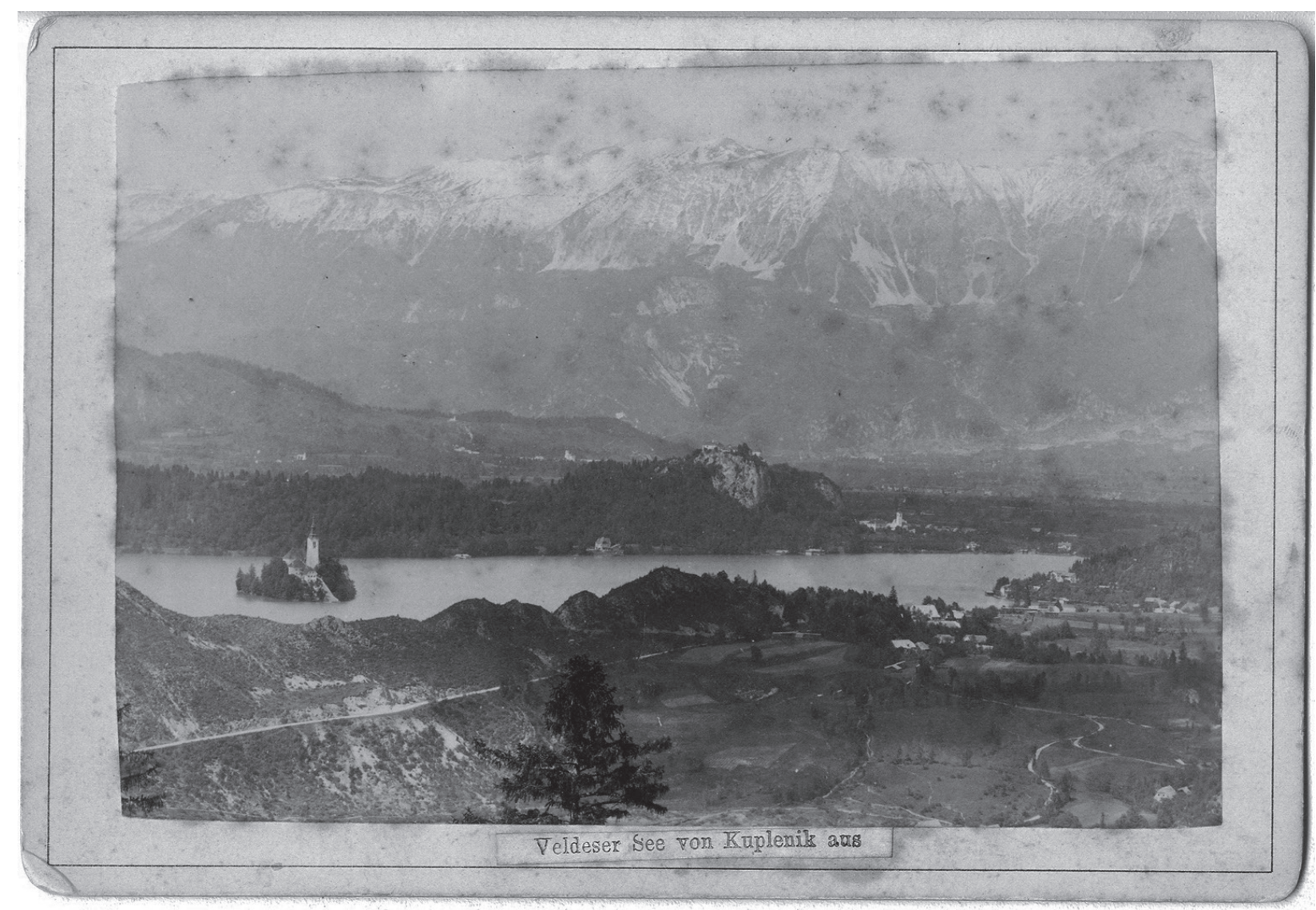

Figure 3: Foxing on the front and back side of an albumen photograph from the end of the $19^{\text {th }}$ century, view of Lake Bled (Photo: Lucija Planinc)

\section{Mould}

Mould grows best in damp, warm, dark and poorly ventilated rooms. It can permanently damage or completely destroy all organic materials on photographs (paper, gelatin, collodion, etc.).

Usually, it is only noted when it becomes visible to the naked eye (see Fig. 4); in the initial phase, it can be seen with a microscope. Active mould is damp, mucous and leaves a stain when touched, while inactive mould is dry and dusty.

16. Lavédrine, Bertrand: Preventive Conservation of Photograph Collections (a guide to). Los Angeles: The Getty Conservation Institute, 2003, pp. 8-12. 


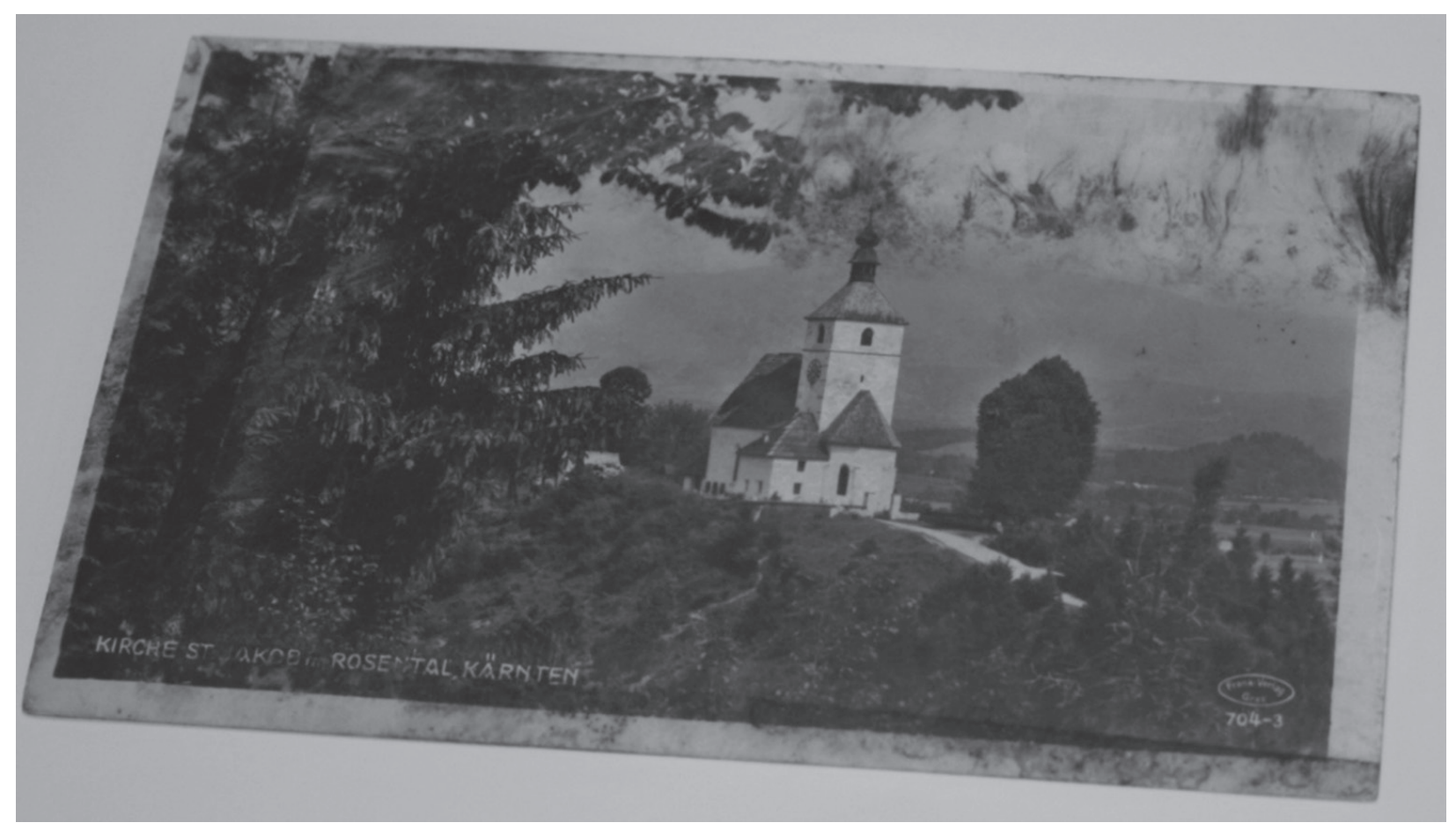

Figure 4: Mould on the front side of a silver gelatin black and white photograph dated 1931-1932, St. Jacob’s Church, Rož / Rosental (Photo: Lucija Planinc)

\section{Curling, bending and folding}

Improper storage and incorrect handling can cause bends or folds in photographs. Often this results in only minor damage and the photographs just need to be flattened. Photographs can also become detached from their secondary support.

\section{Silver mirroring ${ }^{17}$}

A bluish metallic sheen or silver mirroring is the most frequent damage that appears on the binder layer of silver gelatin photographs. It can be found on the dark parts of photographs, and also on negatives. A silver sheen appears as a kind of mirror when a photograph is observed and moved at different angles or directly illuminated from the side. The deterioration of the support or binder layers is caused by polluted air and moisture.

\section{Other types of damage}

Tears, missing areas of primary paper support, and image layers were also found. Most photographs had fingerprints, rust from metal clips, dust, scratches, and notes made by different pens (ballpoint, graphite pens, and various colour pencils). The handwriting mirrors or seeps through the primary paper support to the front side of the photograph, primarily regarding postcards.

$\overline{\text { 17. Reilly, James. M }}$ : $19^{\text {th }}$-Century Photographic Prints (Care and Identification of). New York: Eastman Kodak Company, 2001, p. 47. 


\section{DISCUSSION}

\section{Assessment of the preservation status of the photographs}

The preservation status of the photographs was assessed and the intensity of the conservation treatment required was determined during their examination and inventorying. The following was established:

- the condition of the photographs is satisfactory or good, as the proportion of severely damaged photographs is small;

- the intensity of the required conservation treatment is low (in the aforementioned form indicated as required);

- the photographs need to be physically protected by wrappings and boxes and placed in a suitable room ensuring appropriate climate conditions for permanent storage.

\section{Conservation of damaged photographs}

The conservation treatment is aimed at preserving photographs in good condition; the various treatment procedures are intended to ensure their longest possible lifetime. The procedures are preventive (or passive) and active.

All photographs were dry-cleaned. The front and the back sides were cleaned using an eraser (Magic Rub Stanford ${ }^{\circ}$ ), all the dirt, such as dust and other removable particles, was removed, including silver mirroring on the front side of the photographs, which was found on almost all silver gelatin photographs. The rust was removed mechanically. The missing areas of the photographs were infilled with Japanese paper suitable for this purpose, and, in the same way as for dealing with tears, adhered using a starch adhesive. The highest quality special colours (Winsor \& Newton ${ }^{\circ}$ ) were used to retouch the missing image layers.

A large number of photographs were severely bent due to their improper position and storage in dry rooms; they were moistened and left to flatten between heavy wooden boards for an extended period.

\section{Physical protection of photographs}

The boxes and wrappings are made of material that complies with ISO Standards 14523 and 10214. The wrappings are made of durable paper, $100 \%$ cotton, lignin free, neutral ( $\mathrm{pH} 7)$, of natural colour, 120 $\mathrm{g} / \mathrm{m} 2$ grammage, and free of optical brighteners and calcium carbonate. This type of quality paper (which has passed the PAT test) is appropriate for all types of photographs identified (see Fig. 5). Wrappings with four flaps were handmade to the dimensions of the individual photographs or groups of photographs. The top flap was marked with the serial number and title of the photograph.

Archival boxes of lower quality were replaced with a box produced by the selected manufacturer, i.e. Gaylord ${ }^{\bullet}$ Such boxes are made of durable paperboard and are intended for the permanent storage of photographs (see Fig. 6). They contain no optical brighteners, no adhesives, and are folded, not glued. They feature a metal support for enhanced stability. This box is placed among other (ordinary) archival boxes on the shelf in the aforementioned repository of the Archives of the Republic of Slovenia. At present, the Archives have no separate room for photographs. 
ATLANTI • $28 \bullet 2018 \bullet$ n. 1

Lucija PLANINC -Marija GRABNAR - Jedert VODOPIVEC TOMAŽIČ: Inventar in zaščita fotografij iz zbirke Julija Felaherja, 91-102

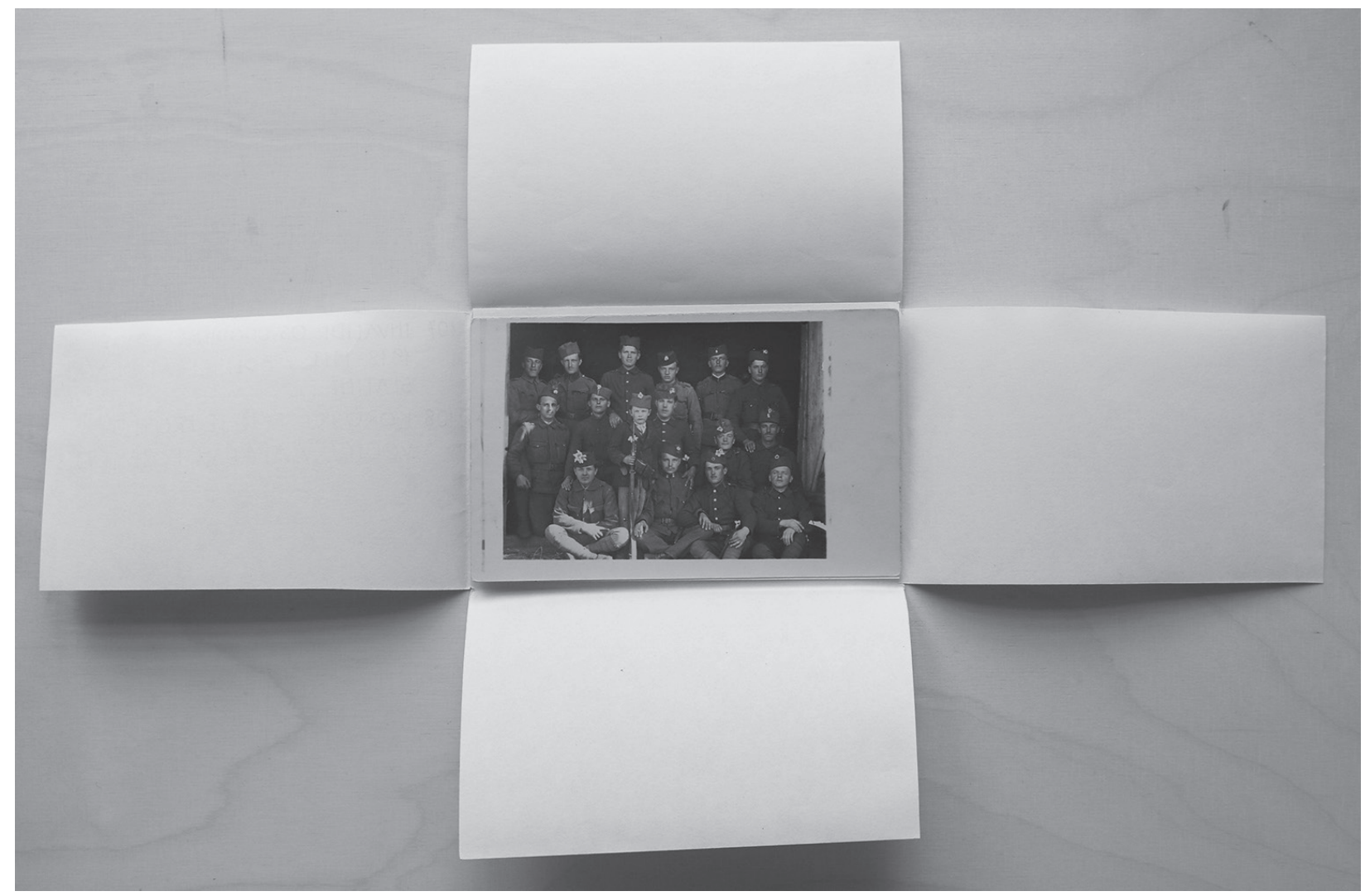

Figure 5: A photograph physically protected with a handmade wrapping with four open flaps (Photo: Lucija Planinc)

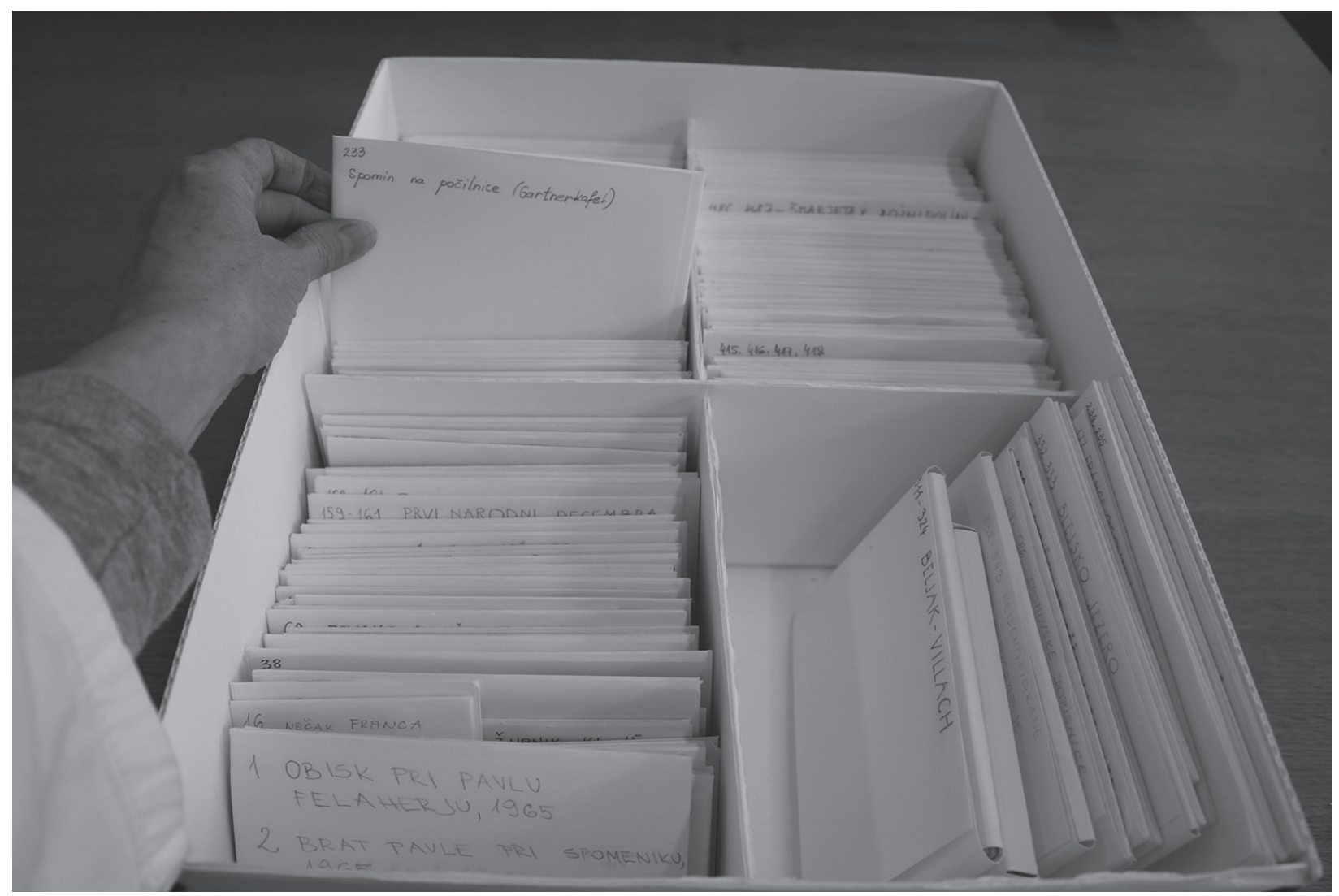

Figure 6: An open archival box made of durable paper with handmade wrappings inside (Photo: Lucija Planinc) 


\section{Sources and References}

Ajdič, Peter (1986). Fotografska kemija 1. Ljubljana: Državna založba Slovenije, pp. 12.

Debevc, Mirjam (2011): Popis in zašcita Julija Felaherja, Elementi popisa fotografij AS 1384 Julij Felaher in materialna zaščita. Graduation thesis. Ljubljana: University of Ljubljana. Faculty of Arts.

Lavédrine, Bertrand (2003). A Guide to the Preventive Conservation of Photograph Collections. Los Angeles: The Getty Conservation Institute.

Lavédrine, Bertrand (2009). Photographs of the Past: Process and Preservation. Los Angeles: The Getty Conservation Institute.

Planinc, Lucija, Grabnar, Marija, Vodopivec Tomažič, Jedert, Debevc Mirjam (2012): Popis in zašcita fotografske zbirke Julija Felaherja. Elementi popisa fotografijfonda AS 1384 Julij Felaher in njegova materialna zašćita, Arhivi, 2012, 35, 1, pp. 249-264.

Reilly, James. M. (2001). 19 $9^{\text {th }}$-Century Photographic Prints (Care and Identification of). New York: Eastman Kodak Company, p. 47.

Tulleken, Kit van (1979). Velika knjiga o fotografiji. Ljubljana: Cankarjeva založba, pp. 154-181.

\section{Websites}

Grafenauer, Danijel (2009): Življenje in delo Julija Felaherja in koroški Slovenci. Doctoral thesis. Maribor: University of Maribor. Faculty of Arts. Avaliable at: http://dkum.uni-mb.si/IzpisGradiva.php?id=11339\# (accessed on 25 February 2011).

\section{SUMMARY}

The paper deals with the census and material protection of the photographs from the personal fond SI AS 1384 Julij Felaher, which is stored in the National Archives of the Republic of Slovenia. Due to the content, and especially because of the rareness of some recordings, the photographs are classified as archival material, which is of utmost importance to the history of Carinthian Slovenes. The goal was to create a transparent and comprehensible model for photo inventory, assess the conservation status, identify the types of photos, identify and then conserve and restore the damage and regulate the appropriate material protection. During the process all photographs were digitized. The description of 604 photographs was carried out in the following successive phases: numbering, technical identification of various types of photographs and simultaneous input of data into the census form. In addition to basic data required by archival description (such as title, year of creation, photograph, studio), the description also includes the size of the photo, the type of photo, the type of damage and the assessment of the conservation status. The data is summarized in a transparent descriptive table, with which we assessed the conservation status. With the practical treatment of photographs, we came to the following findings and conclusions: most, 80 percent of the photographs are analogue (among them 11 negatives) and the rest 20 percent are photomechanical. About $5 \%$ are colored and $95 \%$ black and white. Color photographs are only photomechanical, since photographs were made between 1887 and 1965, before a color analogue photo appeared. The majority are of standard size $9 \times 13$ centimeters, the largest being $19 \times 25.5$ centimeters and a minimum of $5.7 \times 5.3$ centimeters, including in the card and cabinet format. Despite the inadequate storage, there was only just a few damaged photographs, so we assessed their condition as well. There was some mechanical damage such as: lacerations, missing parts, twisting, almost all of them were dusty. We first cleaned dust and other impurities from their surfaces and then conserved and restored all the injuries. Regarding the types of photographs, we selected the materials for permanent preservation of photographs that meet ISO 14523 and 10214 standards. We made the wraps from permanently durable paper, which are sealed on four lids, manually tailored to each photograph or groups of photos. On the top cover we wrote the serial number of the photo and its title. We replaced non-quality archival boxes with a box of permanently durable cardboard, which is intended for permanent storage of photographs. Photographs are stored among the remaining records of the fond on the shelf in the storage unit of National Archives of the Republic of Slovenia in the Virant House. Microclimatic conditions there meet the conditions for permanent storage of these types of photographs. With this pilot project, we wanted to lay the foundations for the appropriate integral material storage of photographic collections in the archives.

Typology: 1.04 Professional article

Submitting date: 02.07.2018

Acceptance date: 08.08.2018 